\title{
THE REORGANIZATION OF GOVERNMENT STRUCTURES TO FACILITATE THE PROCESS OF REUNIFICATION
}

\author{
Tobin Im*
}

\begin{abstract}
This study aims at designing a government structure that would be most appropriate for a reunified Korea. Specifically, I will examine (a) the theoretical considerations involved when shaping government structures; (b) the main function that the unified government should emphasize; and (c) provide some alternatives of departmentalization in terms of the number of ministries and the organizational chart of the future government.
\end{abstract}

\section{INTRODUCTION}

\section{The Importance of this Study}

Until recently, much of Korea's reunification research was limited to discussions concerning possible unification and post-unification problems (for example, Kim Yeon Chul, 1999; Cheon Seong Whun, 1999). Such studies conducted by political scientists and economists were often too abstract and macro in nature to be implemented, if at all required. Nevertheless, the need for policy-makers to anticipate the myriad array of possible scenarios surrounding the reunification process is as urgent as ever. For this reason, it is time to study government structures at a micro and practical level, the level of government that will be responsible for the implementation after reunification, for the purpose of discovering the most appropriate political arrangement for the new Nation.

Governmental structures can affect the outcome of policies, and by extension, the general direction of a nation as a whole. If a government is well designed and its different components perfectly

\footnotetext{
* Professor, Graduate School of Public Administration, Seoul National University
}

coordinated where legitimacy is established, it can achieve its goals efficiently even in turbulent times. It is anticipated that the united government will play a more important role especially in the wake of reunification to pacify possible turbulent and chaotic times. If so, the government must respond in a legitimate and competent manner if it hopes to gain the confidence of the populace and maintain its social order. If the government fails to play its expected role during reunification, the consequences could be traumatic. For these reasons, this study will focus on finding the best model of central government for the period after reunification.

\section{THEORETICAL BACKGROUND}

\section{The Relation between Society and Government}

Historically, there are two approaches on the method of designing a departmental structure of a government: the top-down and the bottom up. The former is exemplified in many European and Asian countries, where a king (and/or a strong state) plays a dominant role in the society. In these countries, the origin of a ministry is an advisor or a chief secretary of the king. In their nascent stage, most of these countries had six essential ministries such as 
War, Interior, Construction, Justice, Administration, and Commerce (Timsit, 1987; Kim Un-Tae, 1995; Kiyoaki Tsuji, 1984: 2 3). New ministries were created mainly from the ministry of the Interior when politicians found it necessary (Timsit, 1987). The latter model is most prominently exemplified by the USA, in the sense that strong interest groups have had a secretary created at the federal government(for example that of agriculture in 1862 , that of education in 1867 , that of labor in 1888) (Seidman, 1998: 164). Here, the people's demands are more important than the wisdom of top political leaders.

The two approaches, being ideal types in the Weberian sense of the term, invariably shade into each other when closely examining each country's experience. Political leaders of top-down countries usually take into account public opinion when making public decisions. However the bottom-up approach, which can be explained clearly under system theory perspectives, becomes more important, as the democratization of the country develops. According to the systems theory, the political system is a black box which transforms people's needs and supports (and eventually feeds) into government policies (Easton, 1953). The ministerial structure is an essential component of the black box in the political system. This means that shaping a government structure is like a designing the component of the black-box.

There is no such thing as a universal government structure in the abstract, independent of space and time. Therefore it is important to examine the specific needs and conditions that a reunified Korea may require from the future government.

\section{Socio-psychological Aspects}

A reunified government will face a large gap between what the population-especially that of the North-demands and what the government is capable of providing. As time passes only after reunification, the dual expectations of two ancient people (North and South) will be salient. Therefore, the role of government in society will become even more important to meet this new situation. Because a good government will respond efficiently to the dual expectations.

It is extremely difficult to predict what the North Koreans will need shortly after a reunification Maslow's motivation theory (1970) will prove to be helpful in this regard. His theory proposes that the following five basic needs, (1) physiological needs, (2) safety needs, (3) social needs, (4) esteem needs, and (5) self-actualization needs, are related in such a way that the second need will not appear until the prior need is satisfied-and so on with the third, fourth, and fifth need. This study applies his theory to the former North Koreans' needs in the future. It is well known that most of the North Koreans are already deprived of food, housing, access to health care, etc., which means their physiological needs are not satisfied. It is probable that the reunified government's policy have to concentrate on satisfying their lower needs such as physiological needs at least immediately after the reunification.

In addition, according to the German experience, the pressure on nation-state building will be heavier as time passes. North Koreans will feel their social and self-esteem needs unsatisfied, and they will begin to count themselves as a second-rate citizens compared to the South Koreans. It is very likely, if the future government does not respond appropriately, that the people's support will decrease and the demand for a strong and efficient government will increase. The future government, if it hopes to administer effectively, must obtain the legitimacy from the people by being efficient in implementing policies.

\section{DESIGNING GOVERNMENT ORGANIZATIONS}

The various departments in the central govern- 
ment are important tools to administer policies formed by constitutional organs. "Departmentalization" concerns the division of labor inside government. For the purpose of this paper, one important criteria of "departmentalization" is efficiency. I will examine, first, the problems of the current two governments and, second, argue the size of the government, its functions, and its form, etc.

\section{Problems of Two Korean Governments' Structures}

The well-known criteria concerning departmentalization are geographical area, function, client, and purpose (Gulick, 1937: 12). Every government in the world is a mixture of these principles (Cho, 1994). This study is especially concerned with the geographical criterion, because reunification will enlarge the geographical area to be governed. Several new functions will be required for the unified government, since it will represent a larger area than either of the individual governments prior to reunification. This geographical change will require a new political landscape. I will examine why the current departmentalization of south as well as the north are not fit to the reunification. On the one hand, in the current South Korean government, three categories of ministry exist in terms of the geographical domain; (1) most departments are assigned to the territory of South Korea; (2) the Ministry of Foreign Affairs and Trade works with foreign countries; (3) the Ministry of Unification works to foster reunification with North Korea. In the present government, the Ministry of Unification monopolizes relations with the North. The current Ministry of Unification is composed of 5 bureaus with 26 divisions: Planning and Management Office, Unification Policy Office, Information Analysis Bureau, Intra-Korean Exchange and Cooperation Bureau, and Humanitarian Affairs Bureau. The Ministry's main function is to gather information about North Korea and support political, humanitarian, cultural, economical exchanges with the North. Information gathering is very difficult due to the fact that the North Korean society is completely closed from the outside. This makes the organization's role as information gatherer rather minimal, since any information that is obtained is so sensitive in nature that it can only be acquired by the Korean Central Intelligence Agency, an agency that is separate from the Ministry of Unification. The second function of the Ministry is also minimal-the Ministry only has authority to authorize contacts with North Koreans rather than initiate contact themselves. If reunification is to be had, the Ministry of Unification should be completely reformed.

With respect to the North Korean government, it has many organizational peculiarities in comparison with most capitalist countries. One of them is the organizational osmosis between the political party and the state administration ( Lee Kang-Lae, 1995 : 78). The Communist Party of North Korea prevails in policy-making and implementation, which is contrary to western democratic principles. Therefore, to separate the political structure from the administrative structure will be the first and fundamental task of the North for reunification.

Another peculiarity of the North Korean administration is the large number of ministries, with 59 executive positions at the upper level (Jung YongDuck, 1993: 368 ; Yang Sung-Chul, 1993: 473). North Korea has created many upper level positions to reward party members. The actual authority of the ministers is very limited even if the title or position may rank very high in the organizational chart. This inflation at the administration level may mean that the actual function is equivalent to a much lower position in the South Korean government. In the process of re-organizing the government structure after unification, a number of these positions in the North will surely have to be reduced.

Also, drastically downsizing the North Korean bureaucracy is necessary and inevitable. The amount 
of government spending and its proportion to the GNP $(67.1 \%)$ in North Korea is much larger than that in South Korea (19.5\%) (Jung Young-Duck, 1993: $366 \sim 367$ ). This is even true in the area of the Ministry of Defense, especially military manpower.

\section{Designing Alternatives of Departmentalization}

Number of Departments

In the South Korean government, the number of ministries varies between 11 and 17 . However, if the number of similar organizations to ministries such as boards, agencies, administrations, etc. are included, the total size of the government would vary between 15 and 58 depending on the Administration. Even though every government in Korea's political history has attempted to downsize itself, each government has continued to grow larger (IM, 1998: 213 214). And as the numbers increase, working together as a collective becomes difficult when coordination and integration are required. This is all the more true when working with organizations of a different country with different political ideologies. Therefore, the number of departments in the unified government should be restricted.

Nonetheless, adding some ministries for a short period following the unification is permissible since the amount of work required during this transitional period will be exceptionally great. There is a historical precedent for this. In Germany, the number of federal ministers varied between 13 and 21 since the beginning of German federalism. However the number increased for some weeks just after the reunification, because some ministers of Lander joined the federal government for a special mission (Busse, 1996: 293). Likewise, succeeding ACDPU and Ministry of Unification, a large ministry (or two or three small services such as property registration, job training, etc.) might be created for a short period to deal with the transformation of the North Korean society.

Finally, we must pay special attention to the problem of dealing with the public employees of North Korea. Most North Korean employees will not be competent to work in the new government, but there are too many of them to be released or retrained in a short period of time. There may be no choice but to let some of them integrate themselves into civil service for the reunified Korea especially during the transition period. After reunification, The Republic of Federal Germany treated about 2.2 million public employees who had worked for the former Republic of Democratic Germany as civil servants (Konig, 1996: 260).

\section{Which Ministerial Functions Should Be Emphasized}

First of all, we should consider what functions of the government will have the most demand after reunification. To clarify this problem, we must think about the tools of government. C. Hood (1986:1 12) classified the activities of a government into four types (tools): communicating, exchanging, determining and directly acting. Focusing on the government-society interface, he summarized basic resources for each activity as follows: nodality for communicating, treasure for exchanging, authority for determining, and organization for directly acting. In North Korea, the government monopolizes in communicating, determining and directly acting while in South Korea, the exchange of activities is more developed.

The mode of governmental tools determines the functions of government. It is important to predict the functional areas that the unified Korean government would have to intervene directly into the lives of its citizens. From a strategic perspective, developing North Korea's economy so that it is equivalent with South Korea will be the most urgent mission, since the large difference will prevent economic growth and social solidarity. As a study about the adaptation of North Korean immigrants to South 
Korean society shows well, the unified government's close and constant intervention with employment concerns are strongly required (Kim Haksung, 2000). The current ministries or governmental functions of South Korea can be classified in terms of their relative growth of the work required after reunification: low, medium, and high (See table 1 below). This categorization is based on the following assumptions, which is also that suggested by Maslow's theory:

- The material aspects of North Korean life (infrastructure, economy, welfare etc.) are more urgent than non-material aspects (culture, education, etc..)

- The government can not do everything al once; it is necessary to concentrate on (or prioritize) certain functions before others.

These assumptions, based on maslow's theory, indicate that a step-by-step approach is better than a wholesale effort to integrate the northern area into a homogeneous Korea. All functions classified as "high" have more or less an economic function, except government information, which concerns the symbolic and psychological interactions with the people.

The function of government information that Hood (1992) named "communicating" is essential because this tool of government can be used to properly inform and educate dissatisfied citizens of the South as well as the North in ways that would satisfy their social and esteem needs.

An emphasis should be placed on these "high" functions during the period after reunification. However, whether the function is classified as low, medium, or high, almost every ministry (and function within each ministry) will have much more supplemental work to do after reunification. In other words, this categorization does not rank what functions are most important, but what functions are most urgent under severe time and resource constraints.

\section{Form of Government Structure at the Ministerial Level}

The main functions of the current South Korean Ministry of Unification will lose its raison d'etre when unification occurs. However, organizations like the Ministry of Unification tend to alter their goals when they are no longer relevant (Blau, P. and W. R. Scott, 1961: 228 233). Therefore, it is very likely that the Ministry of Unification will attempt to keep its personnel and try to redefine its role after reunification. No doubt, that Ministry will be the best and most knowledgeable organization concerning North Korea in the future government. They will almost certainly argue that their expertise

Table 1. Categorization of Ministries (Ministerial functions)

\begin{tabular}{|c|c|c|c|}
\hline Relative growth & Low & Medium & High \\
\hline $\begin{array}{l}\text { Ministerial } \\
\text { Functions }\end{array}$ & $\begin{array}{l}\text { - unification } \\
\text { - women's affaire } \\
\text { - defense } \\
\text { - foreign affaires } \\
\text { - trade } \\
\text { - environment }\end{array}$ & $\begin{array}{l}\text { - home affaires } \\
\text { - justice } \\
\text { - culture and tourism } \\
\text { - education } \\
\text { - planning and } \\
\text { budgeting } \\
\text { - finance and } \\
\text { economy }\end{array}$ & $\begin{array}{l}\text { - healih and welfare } \\
\text { - construction and } \\
\text { transportation } \\
\text { - agriculture and } \\
\text { forestry } \\
\text { - commerce and } \\
\text { industry } \\
\text { - labor, especially job } \\
\text { training } \\
\text { - government } \\
\text { information } \\
\text { - patrimony }\end{array}$ \\
\hline
\end{tabular}


demands an instrumental position somewhere within the new government.

One possibility is to transform the Ministry into what could be called the Ministry of the North, with policy and administrative duties in the economy, education, construction, etc., concerning, what could then be, the former North Korea. This would free up the current Ministries (from the former South Korea) to concentrate more upon the problems like the serious lack of means of implementation, the lack of personnel and organization, and conflicts with the other ministries working for the former South Korea. The problem we can anticipate is that there would probably be competition between the ministry of the North and the other Ministries for resource allocations.

Another possibility is to remove the Ministry of Unification and to expand existing Ministries of the south Korean government, by size and function, to include the former North Korea. This expansion would require a considerable number of trained personnel. Whatever the departmentalization of the future government would be, the lack of personnel for implementing policies in Northern area will be the most important issue. Using former North Korean bureaucrats might be one solution: each Ministry could merge its counter-unit of the current North Korean Ministries.

Therefore there are at least two ways of organizing ministries to reflect the important functions of the government mentioned above. One is to create one ministry which will do almost all functions of priority work in the northern area, and the other is to have every ministry extend their coverage into the northern area as far as each function is concerned.

The first option seems to me better only if it is deployed for a short period of time after reunification. The size of this ministry, which we might call 'Ministry of North,' could be relatively large because it would have to comprise of many bureaus (or administrations) of the "high" governmental functions mentioned above: land property and use, health and welfare, construction and transportation, agriculture and forestry, commerce and industry, labor etc.. The other Ministries would only be responsible to deal with the meta policies for the unified Korea on the one hand and the implementation of their proper functions on the southern area on the other hand. Therefore, the Ministry of North's role would concentrate on implementing rather than forming policies. If the future Constitution adopts a federal system, the main sub-units belonging to the Ministry of North would become independent ministries.

The advantages of this option are that it minimizes reunification shock by separating governmental work by geographical area and it reemployes the manpower and knowledge-base of the former North Korea. Employees working at the Ministry of Unification for the former South Korea and most of the former North Korean technocrats who were not too political and proved themselves as experts could join this ministry.

Nevertheless, this option has a distinct disadvantage. The problem of coordination will arise even if the work of the ministry of North concentrated on implementation, because policy formation and implementation can not be separated so clearly.

The second option would not require a new ministry. However, this would mean that the size and the volume of the work of every ministry would be sharply increased. Because of the new requirements, it would be preferable to integrate some experts from the former North Korean bureaucracy to each ministry to the extent necessary. Therefore, at the intra-organizational level of Ministry, there will be those who know the North relatively well and those who do not. No doubt there will be different values and approaches at work in groups within the Ministries. As bureaucrats form and implement policies, there could be potential conflicts between civil servants acquainted with the North and those who are not. An excessive 
Figure 1. An Example of Ministerial Structure for Option 1

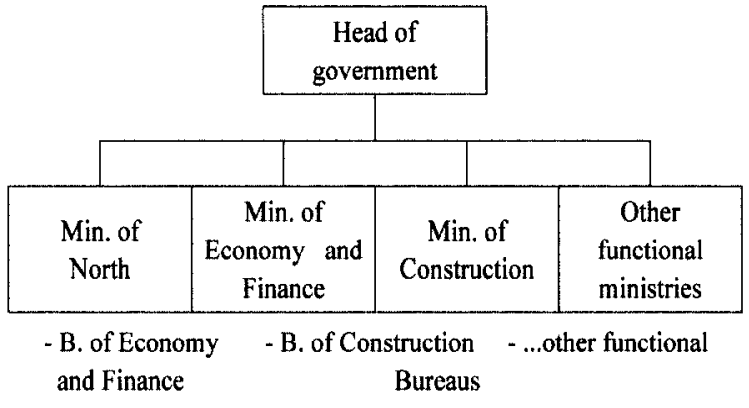

Figure 2. An Example of Ministerial Structure for Option 2

\begin{tabular}{|c|c|c|c|c|}
\hline & \multicolumn{3}{|c|}{$\begin{array}{c}\text { Head of } \\
\text { government }\end{array}$} & \\
\hline $\begin{array}{l}\text { Min. of } \\
\text { Education }\end{array}$ & $\begin{array}{l}\text { Min. of } \\
\text { Economy and } \\
\text { Finance }\end{array}$ & \multicolumn{2}{|c|}{$\begin{array}{c}\text { Min. of } \\
\text { Construction }\end{array}$} & $\begin{array}{l}\text {..other } \\
\text { functional } \\
\text { ministries }\end{array}$ \\
\hline \multirow{2}{*}{$\begin{array}{l}\text {-B. of School } \\
\text { for North } \\
\text {-B. of School } \\
\text { for South } \\
\text {-Other B. }\end{array}$} & \multicolumn{2}{|c|}{$\begin{array}{l}\text {-B. of Planning } \\
\text { for North }\end{array}$} & \multicolumn{2}{|c|}{$\begin{array}{l}\text {-B. of Road } \\
\text { for North }\end{array}$} \\
\hline & \multicolumn{2}{|c|}{$\begin{array}{l}\text {-B. of Planning } \\
\text { for South }\end{array}$} & $\begin{array}{l}-B . \text { of } R \\
\text { for Sou }\end{array}$ & \\
\hline -Other B. & \multicolumn{2}{|l|}{ Other B. } & \multicolumn{2}{|c|}{ Other $B$. } \\
\hline \multicolumn{5}{|c|}{ * Min. refers to Ministry } \\
\hline
\end{tabular}

conflict requires special coordination and if the cost for the coordination is too high, organizational efficiency would decrease.

From a coordination perspective, option one would be more efficient than option two during the first period after reunification, since the distinct problems of the North and South would be too different and large to be handled within each ministry. But, as this gap becomes narrower, the second option would become more efficient from a certain point.

\section{CONCLUDING COMMENT}

The South Korean administration itself has many problems, of which democratization and decen- tralization are the most important (Kim BunWoong, 1993). In addition to these problems, the South Korean government will have to handle the huge and burdensome work of integrating the North and the South when reunification occurs. Designing a central government structure is most important. Government structures have two functions; (1) a symbolic tool or representative tool giving psychological satisfaction to the people, and (2) a technical tool helping to coordinate government work more efficiently.

This study focus on the design of government structure at ministerial level. At the constitutional level, shifting to a parliamentary system with a second chamber is recommended for representation and institutional cost. At the ministerial level, I identified several functions of priority as well as offer a possible form of ministerial structure.

Nevertheless, it should be emphasized that a perfect structure does not exist and that a good structure does not guarantee good operation. Concerning their operations, we have to remember that both the present South and North Korean administrations are working authoritatively and unilaterally in relation to their citizens. But whatever the government structure will be, the level of dissatisfaction of former North Koreans as well as former South Koreans will grow as time passes after reunification. The problem of dissatisfaction can be treated on the operational level of the administration.

To conclude, inspired from the critiques of the French administration model (Calman and Talmant, 1997), I can suggest the following recommendations:

- to identify the pertinent levels of action and decision making along line of government structure.

- to abandon the top-down thinking and undertake a genuine dialogue with the public.

- to provide officials with an opportunity to draw up, with the public for which they are responsible, the orientations that need to be taken. 


\section{Bibliography}

Baudura, Peter. 1996. Le cadre constitutionnel. Revue Francaise d'Administration Publique. avril-juin. N.78.

Blau, Peter, M. and W. R. Scott. 1962. Formal Organizations. Chandler publishing.

Busse, Volker. 1996. L'Administration Federale. Revue Francaise d'Administration Publique. avril-juin. N.78.

Calmane, Pierre and A. Talmant. 1997. L'Etat au Coeur. Paris: Desclee De Brouwer.

Cheon Seong Whun. 1999. National Interests and National Strategy of South Korea: A Focus on Unification, Diplomacy and Security. National Strategy. Vol.5, N.2. Seoul: The Sejong Institute (in Korean).

Cho, Suk-Choon. 1994. Theories of Organizations. Seoul: Bupmun-sa. (In Korean).

Easton, David. 1953. The Political System. New York: Alfred A Knopt. (In Korean).

Gulick, Luther H. 1937. Notes on the Theory of Organization. In Papers on the Science of Administration, edited by Gulick and Lyndall Urwick. New York: Institut of Public Administration.

Hood, C. 1986. The Tools of Government, Chatham. New Jersey: Chatham House Publishers, Inc.

IM Tobin. 1997. Local Organizations in Korea. Seoul: Bakyoung-sa. (In Korean).

IM Tobin. 1998. On Central Government Organization. In Korean Public Administration, edited by Kang In-Jae and Lee Dal-Gon. Seoul: Daeyoungmunwha-sa. (In Korean).

Jung Yong-Duck. 1993. The Politico-Administrative Institutions and Reunification of Korea. In Korean Public Administration and Policy in Transition, edited by Kim Kwang-Woong and Jug Yong-Duck. Seoul: KAPA \& Jangwon.
Kim Byung-Jun. 1998. Korean Decentralization. Seoul: Bupmun-sa.

Kim Ho-Sup. 1998. The President. In Modern Korean Government, edited by Ha Tae-kwon et al. Seoul: Bupmun-sa. (In Korean).

Kim Un-Tae. 1995. Politico-administrative History of Chosun Dynasty. Seoul: Pakyoungsa. (In Korean).

Kim Yeon Chul. 1999. A Strategy for the Improvement of Inter-Korean Relations. National Strategy. Vol.5, N.2. Seoul: The Sejong Institute.

Kim, Bun-Woong. 1993. The Democratization of Public Administration in Korea. In Korean Public Administration and Policy in Transition, editied by Kim Kwang-Woong and Jung Yong-Duck. Seoul: KAPA \& Jangwon.

Kim, Hak-sung. 2000. A Study on adaptation of North Korean immigrations to South Korean society. A thesis submitted for the MPA, Seoul National University. (In Korean).

Kiyoaki Tsuji. 1984. Public Administration in Japan. Tokyo: University of Tokyo Press.

Konig, Klaus. 1996. Classicisme et Modernisme de l'Administration Allemande. Revue Francaise d'Administration Publique. avril-juin. N.78.

Lee Kang Lae. 1995. A Study on the Nature of North Korean Bureaucracy and its Changing Process. Ph. D. dissertation, Seoul National University. (In Korean).

Maslow, A. 1970. Motivation and Personality. New York: Harper \& Row.

Seidman. 1998. Politics, Position and Power. 5rd ed. Oxford: Oxford University Press.

Timsit, G. 1987. Administrations et Etats: etude comparee. Paris PUF.

Yang Sung-Chul. 1993. A Study on Politics of North Korea. Seoul: Pakyoung-sa. (In Korean). 